\title{
EFEKTIFITAS PEMBERIAN KOMPRES HANGAT TERHADAP SUHU TUBUH PADA ANAK DENGAN PENINGKATAN SUHU TUBUH DI RUANG EDELWEIS RSUD DR. M. YUNUS BENGKULU
}

\author{
Esti Sorena, Samwilson Slamet, Benny Sihombing \\ Program Studi D3 Keperawatan FMIPA, Universitas Bengkulu,Bengkulu Indonesia \\ Email; estisorena@gmail.com
}

\begin{abstract}
Abstrak
Demam merupakan salah satu sebab yang sering membuat orang tua segera membawa anaknya berobat. Panas atau demam kondisi dimana otak mematok suhu di atas setting normal yaitu di atas 38oC. Namun demikian, panas yang sesungguhnya adalah bila suhu $>38.5$.C. Salah satu tindakan nonfarmakologi yang dapat dilakukan untuk penurunan panas adalah dengan kompres. Kompres adalah salah satu metode fisik untuk menurunkan suhu tubuh anak yang mengalami demam. Tujuan penelitian in adalah untuk mempelajari efektifitas pemberian kompres hangat terhadap suhu tubuh pada anak dengan peningkatan suhu tubuh di ruang edelweis RSUD Dr. M. Yunus Bengkulu.Desain yang digunakan dalam penelitian ini adalah Quasi Eksperimental menggunakan The One Group Pretest Postest Design. Populasi dalam penelitian adalah seluruh pasien anak yang mengalami peningkatan suhu tubuh di Ruang Edelweis RSUD Dr. M. Yunus Bengkulu pada bulan Mei 2018. Pengambilan sampel dalam penelitan ini menggunakan teknik accidental sampling sebanyak 19 responden Pengumpulan data dalam penelitian ini menggunakan data primer dan data sekunder. Hasil penelitian didapatkan : kecenderungan penurunan suhu tubuh setelah dilakukan kompres hangat pada anak dengan peningkatan suhu tubuh di ruang Edelweis RSUD Dr. M. Yunus Bengkulu dengan rata-rata penurunan $\left(0,7526^{\circ} \mathrm{C}\right)$. Diharapkan perawat anak dapat mengimplementasikan intervensi kompres hangat pada peningkatan suhu tubuh yang di rawat di rumah sakit atau yang di rawat di rumah.
\end{abstract}

Kata Kunci: Kompres Hangat, Suhu Tubuh

\section{Latar Belakang}

Permasalahan anak sakit merupakan permasalahan yang kompleks di Indonesia. Indonesia merupakan negara dengan angka kematian anak 27 per 1000 kelahiran hidup (UNICEF, 2015). Pada masa usia prasekolah aktifitas anak yang meningkat menyebabkan anak sering kelelahan sehingga menyebabkan rentan terserang penyakit akibat daya tahan tubuh yang lemah pula hingga anak diharuskan untuk menjalani hospitalisasi. Hasil survei UNICEF (2012), menunjukkan prevalensi anak yang menjalani perawatan di rumah sakit sekitar $84 \%$.

Di beberapa negara berkembang yang mencatat bahwa angka kematian akibat kesakitan pada balita itu berada pada 
kisaran 40 per 1000 kelahiran hidup. WHO sendiri mengungkapkan bahwa sampai tahun 2012 terdapat 13 juta balita telah meninggal tiap tahunnya data tersebut kemungkinan bertambah setiap tahunnya rata-rata kejadian meninggalnya bayi dan balita ini berada di negara berkembang, termasuk indonesia (Hartini, 2015)

Angka kesakitan anak di Indonesia berdasarkan Survei Penduduk Antar Sensus (SUPAS) tahun 2015 di daerah perkotaan menurut kelompok usia 0-4 tahun sebesar 25,8\%, usia 5-12 tahun sebanyak $14,91 \%$, usia 13-15 tahun sekitar 9,1\%, usia 16-21 tahun sebesar 8,13\%. Angka kesakitan anak

Salah satu tindakan nonfarmakologi yang dapat dilakukan untuk penurunan panas adalah dengan kompres. Kompres adalah salah satu metode fisik untuk menurunkan suhu tubuh anak yang mengalami demam. Pemberian kompres hangat pada daerah pembuluh darah besar merupakan upayamemberikan rangsangan pada area preoptik hipotalamus agar menurunkan suhu tubuh. Sinyal hangat yang dibawa oleh darah ini menuju hipotalamus akan merangsang area preoptik mengakibatkan pengeluaran sinyal oleh sistem efektor. Sinyal ini akan menyebabkan terjadinya pengeluarn panas tubuh yang lebih banyak melalui dua mekanisme yaitu dilatasi pembuluh darah perifer dan berkeringat (Potter \& Perry, 2012)

$$
\text { Dengan kompres hangat }
$$

menyebabkan suhu tubuh diluaran akan terjadi hangat sehingga tubuh akan menginterpretasikan bahwa suhu diluaran cukup panas, akhirnya tubuh akan menurunkan kontrol pengatur suhu di otak supaya tidak meningkatkan suhu pengatur tubuh, dengan suhu diluaran hangat akan membuat pembuluh darah tepi dikulit melebar dan mengalami vasodilatasi sehingga pori - pori kulit akan membuka dan mempermudah pengeluaran panas. Sehingga akan terjadi perubahan suhu tubuh (Purwanti, 2015)

Berdasarkan data rekam medik RSUD Dr. M. Yunus Bengkulu didapatkan jumlah pasien anak yang dirawat pada tahun 2016 mencapai 928 orang, tahun 2015 meningkat menjadi 945 orang dan tahun 2017 meningkat menjadi 1.380 orang. Sedangkan data yang diperoleh dari ruang edelweis jumlah anak yang dirawat pada bulan Januari - Maret 2018 sebanyak 290 orang. Berdasarkan survey awal peneliti di ruang Edelweis didapatkan pada bulan Maret-April jumlah pasien yang dirawat dengan peningkatan suhu tubuh 
sebanyak 24 orangusia 0-21 tahun apabila dihitung dari keseluruhan jumlah penduduk adalah 14,44\% (Kemenkes RI, 2016)

Demam merupakan salah satu sebab yang sering membuat orang tua segera membawa anaknya berobat. Panas atau demam kondisi dimana otak mematok suhu di atas setting normal yaitu di atas $38^{\circ} \mathrm{C}$. Namun demikian, panas yang sesungguhnya adalah bila suhu $>38.5 \mathrm{C}$. Akibat tuntutan peningkatan tersebut tubuh akan memproduksi panas. Sebenarnya panas bukan penyakit melainkan gejala suatu penyakit sebagai reaksi tubuh untuk melawan infeksi atau penyakit, yang bisa disebabkan oleh infeksi virus atau bakteri. Ketika melawan penyakit/ infeksi yang masuk, tubuh akan mengeluarkan sejumlah panas ke kulit tubuh (Hartini, 2015).

Kompres hangat adalah kompres dengan air suam-suam kuku atau air hangat (Rudianto,2010).Manfaat kompres air hangat adalah dapat memberikan rasa nyaman dan menurunkan suhu tubuh. Kompres hangat adalah melapisi permukaan kulit dengan handuk yang telah dibasahi air hangat dengan temperatur maksimal $43^{\circ} \mathrm{C}$. Pemberian kompres air panas/hangat pada daerah tubuh akan memberikan sinyal ke hypothalamus melalui sumsum tulang belakang. Ketika reseptor yang peka terhadap panas di hypothalamus dirangsang, system efektor mengeluarkan sinyal yang memulai berkeringat dan vasodilatasi perifer. Perubahan ukuran pembuluh darah diatur oleh pusat vasomotor pada medulla oblongata dari tangkai otak, dibawah pengaruh hypothalamic bagian anterior sehingga terjadi vasodilatasi. Terjadinya vasodilatasi ini menyebabkan pembuangan/ kehilangan energi/panas melalui kulit meningkat, diharapkan akan terjadi penurunan suhu tubuh sehingga mencapai keadaan normal kembali (Djuwarijah, 2009).Pemberian kompres hangat pada daerah pembuluh darah besar merupakan upaya memberikan rangsangan pada area preoptik hipotalamus agar menurunkan suhu tubuh. Sinyal hangat yang dibawa oleh darah ini menuju hipotalamus akan merangsang area preoptik mengakibatkan pengeluaran sinyal oleh sistem efektor. Sinyal ini akan menyebabkan terjadinya pengeluarn panas tubuh yang lebih banyak melalui dua mekanisme yaitu dilatasi pembuluh darah perifer dan berkeringat (Potter \& Perry, 2012) 
Untuk mempertahankan suhu yang konstan, perawat harus sering mengganti kompres atau menggunakan bantalan akuatermi yang hangat atau bantalan panas kedap air di atas kompres. Karena kelembaban dapat mengantarkan panas, maka untuk membuat kompres lembab, semua pengaturan suhu pada alat pemanas harus lebih rendah dari pada membuat kondisi kering. Lapisan pembungkus plastik atau handuk kering juga dapat mengisolasi kompres dan menahan panas. Panas yang lembab dapat meningkatkan vasodilatasi dan evaporasi panas dari permukaan kulit (Potter \& Perry, 2009)Dengan kompres hangat menyebabkan suhu tubuh diluaran akan terjadi hangat sehingga tubuh akan menginterpretasikan bahwa suhu diluaran cukup panas, akhirnya tubuh akan menurunkan kontrol pengatur suhu di otak supaya tidak meningkatkan suhu pengatur tubuh, dengan suhu diluaran hangat akan membuat pembuluh darah tepi dikulit melebar dan mengalami vasodilatasi sehingga pori-pori kulit akan membuka dan mempermudah pengeluaran panas. Sehingga akan terjadi perubahan suhu tubuh (Purwanti, 2015)
Penelitian ini bertujuan untuk mencari intervensi yang dapat mencegah komplikasi-komplikasi yang mungkin terjadi akibat peningkatan suhu tubuh

\section{METODE PENELITIAN}

Desain yang digunakan dalam penelitian ini adalah Quasi Eksperimental menggunakan The One Group Pretest Postest Design. Teknik yang digunakan adalah observasi yaitu suatu metode dimana pengamat (observer) ikut berpartisipasi dalam kegiatan yang dilakukan (Notoatmojo, 2010). Pengukuran dilakukan sebelum dan sesudah perlakuan sehingga mendapatkan perbandingan. Populasi dan sampel dalam penelitian ini menggunakan teknik accidental sampling yaitu seluruh pasien anak yang mengalami peningkatan suhu tubuh di Ruang Edelweis RSUD Dr. M. Yunus Bengkulu. Pengambilan sampel dilakukan mulai 01 Mei sampai 30 Mei 2018. Data primer yang diperoleh dari observasi langsung dengan Mengukur suhu tubuh responden menggunakan termometer dan pemberian kompres hangat oleh perawat dan data sekunder diperoleh dari buku register dan rekam 
medik pasien yang dirawat di Ruang Edelweis RSUD Dr. M. Yunus

Analisa univariat untuk menganalisa karakteristik demografi dan klinis suhu tubuh anak dengan distribusi frekuensi dan distribusi rerata, Analisa bivariat untuk menganalisa pengaruh intervensi terhadap peningkatan derajat suhu tubuh pre dan post tindakan kompres hangat pada anak yang di rawat di ruang edelweiss RSUD Dr.M.Yunus Bengkulu.

\section{Hasil Penelitian}

\section{a. Analisis Univariat}

Analisis ini dilakukan untuk mendapatkan gambaran tentang masingmasing variabel yang diteliti.

a) Gambaran suhu tubuh sebelum kompres hangat

Tabel 1: Gambaran Suhu Tubuh Sebelum Kompres Hangat Pada Anak Dengan

Peningkatan Suhu Tubuh

\begin{tabular}{|l|l|l|c|}
\hline Minimum & Maksimum & Mean & $\begin{array}{c}\text { Std. } \\
\text { Deviation }\end{array}$ \\
\hline 38 & 40 & 38,55 & 0,5824 \\
\hline
\end{tabular}

\begin{tabular}{lllr}
\multicolumn{2}{c}{ Berdasarkan } & tabel & diatas, \\
didapatkan & bahwa dari 19 & orang \\
anakdengan & yang dirawat & dengan \\
peningkatan & suhutubuh, & sebelum
\end{tabular}

dilakukan kompres hangat, didapat suhu tubuh minimum $38^{\circ} \mathrm{C}$, suhu tubuh maksimum $40{ }^{\circ} \mathrm{C}$ dan suhu tubuh rata-rata $38,55{ }^{\circ} \mathrm{C}$ dengan standar deviasi 0,5824

b.Gambaran suhu tubuh setelah kompres hangat

Tabel 2: Gambaran Suhu Tubuh Setelah Kompres Hangat Pada AnakDengan

Peningkatan Suhu Tubuh

\begin{tabular}{|l|l|l|c|}
\hline Mininum & Maksimum & Mean & $\begin{array}{c}\text { Std. } \\
\text { Deviation }\end{array}$ \\
\hline 36,7 & 39,7 & 37,80 & 0,7427 \\
\hline
\end{tabular}

Berdasarkan tabel diatas, didapatkan bahwa dari 19 orang anak dengan yang dirawat dengan peningkatan suhu tubuh, setelah dilakukan kompres hangat, didapat suhu tubuh minimum $36,7^{\circ} \mathrm{C}$, suhu tubuh maksimum $39,7{ }^{\circ} \mathrm{C}$ dan suhu tubuh ratarata $37,80{ }^{\circ} \mathrm{C}$ dengan standar deviasi 0,7427 .

\section{b) Analisis Bivariat}

Analisis bivariat digunakan untuk mengetahui efektifitas pemberian kompres hangat terhadap suhu tubuh pada anak dengan peningkatan suhu 
tubuh di ruang Edelweis RSUD Dr. M.

Yunus. Dengan hasil sebagai berkut:

Tabel 3 : Efektifitas Pemberian Kompres

Hangat Terhadap Suhu Tubuh Pada Anak

Dengan Peningkatan Suhu Tubuh Di

Ruang Edelweis RSUD Dr. M. Yunus

Bengkulu

\begin{tabular}{|c|c|c|}
\hline Variabel & Rata-Rata & Selisih \\
\hline $\begin{array}{c}\text { Suhu sebelum } \\
\text { kompres }\end{array}$ & 38,558 & \\
\cline { 1 - 2 } $\begin{array}{c}\text { Suhu setelah } \\
\text { kompres }\end{array}$ & 37,805 & 0,7526 \\
\hline
\end{tabular}

Bedasarkan tabel diatas didapat nilai selisih mean antara suhu tubuh sebelum kompres dengan suhu tubuh setelah kompres sebesar 0,7526 bernilai positif, artinya terdapat kecenderungan penurunan suhu setelah dilakukan kompres hangat dengan rata-rata penurunan $0,7526{ }^{\circ} \mathrm{C}$.

Kondisi ini menunjukkan bahwa intervensi kompres hangat memiliki pengaruh yang signifikan terhadap peningkatan suhu tubuh dalam menurunkan suhu tubuh pada anak, hal ini dikarenakan setelah dilakukan kompres hangat pasen merasa nyaman dan terjadi perpindahan panas tubuh. Sesuai dengan teori menurut Djuwarijah
(2009), bahwa manfaat kompres air hangat adalah dapat memberikan rasa nyaman dan menurunkan suhu tubuh. Pemberian kompres air panas/hangat pada daerah tubuh akan memberikan sinyal ke hypothalamus melalui sumsum tulang belakang. Ketika reseptor yang peka terhadap panas di hypothalamus dirangsang, system efektor mengeluarkan sinyal yang memulai berkeringat dan vasodilatasi perifer. Perubahan ukuran pembuluh darah diatur oleh pusat vasomotor pada medulla oblongata dari tangkai otak, dibawah pengaruh hypothalamic bagian anterior sehingga terjadi vasodilatasi. Terjadinya vasodilatasi ini menyebabkan pembuangan/ kehilangan energi/panas melalui kulit meningkat, diharapkan akan terjadi penurunan suhu tubuh sehingga mencapai keadaan normal kembali.

Sejalan dengan teori menurut Kozier (2010), bahwa kompres hangat dapat menurunkan suhu tubuh anak demam karena tubuh dapat melepaskan panas melalui empat cara yaitu radiasi, konduksi, konveksi dan evaporasi. Secara umum tubuh akan melepaskan panas melalui proses konduksi yaitu perpindahan panas akibat paparan 
lansung kulit dengan benda-benda yang ada disekitar tubuh. Biasanya proses kehilangan panas dengan mekanisme konduksi sangat kecil , sedangkan evaporasi (penguapan air dari kulit) dapat memfasilitasi perpindahan panas tubuh. Setiap satu gram air yang mengalami evaporasi akan menyebabkan kehilangan panas tubuh sebesar 0,58 kilo kalori. Pada kondisi individu tidak berkeringat, mekanisme evaporasi berlangsung sekitar 450-600 ml. Hal ini menyebabkan kehilangan panas terus menerus dengan kecepatan 12-16 kalori per jam

Pemberian kompres hangat pada daerah pembuluh darah besar merupakan upaya memberikan rangsangan pada area preoptik hipotalamus agar menurunkan suhu tubuh. Sinyal hangat yang dibawa oleh darah ini menuju hipotalamus akan merangsang area preoptik mengakibatkan pengeluaran sinyal oleh sistem efektor. Sinyal ini akan menyebabkan terjadinya pengeluarn panas tubuh yang lebih banyak melalui dua mekanisme yaitu dilatasi pembuluh darah perifer dan berkeringat (Potter \& Perry, 2012)

Kesimpulan. a. Hasil analisis factor-faktor yang mempengaruhi derajat peningkatan suhu tubuh didapatkan hasil yang signifikan dengan pemberian kompres hangat.

b. Intervensi kompres hangat mempunyai pengaruh yang signifikan terhadap derajat peningkatan suhu tubuh

c. Terdapat kecenderungan penurunan suhu tubuh setelah dilakukan kompres hangat pada anak dengan peningkatan suhu tubuh di ruang Edelweis RSUD Dr. M. Yunus Bengkulu dengan rata-rata penurunan $0,7526^{\circ} \mathrm{C}$

\section{DAFTAR PUSTAKA}

Djuwarijah, dkk. 2009 . Efektivitas Penurunan Suhu Tubuh MenggunakanKompres Air Hangat Dan Kompres Plester Pada Anak Dengan Demam Di Ruang Kanthil Rumah Sakit Umum Daerah Banyumas.

Diakses pada tanggal 12 April 2018, dari http://digilib.ump.ac.id/files/disk1 116 /jhptump-a-djuwariyah-758-1efektivi-.pdf 
Guyton \& Hall. 2010. Buku Ajar Fisiologi Kedokteran. Jakarta: EGC

Hartini, S. 2015. Efektifitas KompresAir Hangat Terhadap Penurunan Suhu Tubuh Anak Demam Usia 1 - 3 Tahun Di SMC RS Telogorejo Semarang. Diakses pada tanggal 121April2018,darihttp://ejournal.s tikestelogorejo.ac.id/index.php/il mukeperawatan /articl e/download/288/312

Hidayat, A. A. 2007. Metode Penelitian Keperawatan dan teknik Analisa Data. Jakarta: Salemba medika

Kemenkes RI. 2016. Profil Kesehatan Indonesia. Jakarta: Kemenkes RI

Kozier. Erb, Berman. Snyder. 2010. Buku Ajar Fondamental Keperawatan: Konsep, Proses \& Praktik. Jakarta: EGC
Nelson, W. E. 2012. Ilmu Kesehatan Anak. Jakarta: EGC

Notoatmodjo, S. 2010. Metodelogi penelitian kesehatan. Jakarta: Rineka Cipta

Potter \& Perry. 2009. Fundamental Keperawatan. Jakarta: Salemba Medika

Potter \& Perry. 2012. Fundamental Keperawatan. Jakarta: Salemba Medika

Purwanti, S. 2015. Pengaruh Kompres Hangat Terhadap Perubahan Suhu TubuhPada Pasien Anak Hipertermia Di Ruang Rawat Inap RSUD Dr. Moewardi Surakarta. Diakses pada tanggal 2 April 2018 , darihttp://ejournal.stikestelogorejo .ac.id/index.php/ilmukeperawatan/ article/download/288/312

Rudianto, S. 2010. Demam Pada Anak. Jakarta: Gramedia Press 